\title{
A Catalytic Kinetic Spectrophotometric Determination of Organophosphorus Pesticides in Vegetable Samples
}

\author{
Neetu Tiwari* and Anupama Asthana \\ Department of Chemistry, Govt. V.Y.T. P.G., Autonomous College, 491001 Durg, Chhattisgarh, India
}

\begin{abstract}
Um método cinético catalítico espectrofotométrico, simples, seletivo e sensível para a determinação de quantidade traço de pesticidas organofosforados foi proposto. O método é baseado no efeito catalítico de pesticidas organofosforados (malationa, dimetoato e forato) na oxidação de LCV (leuco cristal violeta) por iodato de potássio em meio de ácido clorídrico, produzindo um corante violeta. O corante apresenta absorção máxima em $592 \mathrm{~nm}$. O método de tempo fixo foi usado por $15 \mathrm{~min}$. O sistema obedece a lei de Beer no intervalo de 0,02-0,2, 0,032-0,32 e

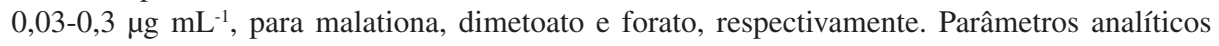
importantes como tempo, temperatura, concentração do reagente, acidez, etc, foram otimizados para reação completa. A sensibilidade de Sandell e absortividade molar para o sistema foram $0,0002,0,0004,0,0004 \mu \mathrm{g} \mathrm{cm}{ }^{-2}$ e $1,2 \times 10^{6}, 5,21 \times 10^{5}, 6,3 \times 10^{5} \mathrm{~L} \mathrm{~mol}^{-1} \mathrm{~cm}^{-1}$, respectivamente. O método proposto foi aplicado satisfatoriamente à determinação de pesticidas organofosforados, em micro concentrações, em amostras vegetais.
\end{abstract}

A simple selective and sensitive catalytic kinetic spectrophotometric method for the determination of trace amount of organophosphorus pesticides has been proposed. The method is based on the catalytic effect of organophosphorus pesticides (malathion, dimethoate and phorate) on the oxidation of LCV (leuco crystal violet) by potassium iodate in hydrochloric acid medium to give a violet colored dye. The dye shows maximum absorption at $592 \mathrm{~nm}$. The fixed-time method was used for $15 \mathrm{~min}$. The system obeys Beer's law in the range of 0.02-0.2, 0.032-0.32 and $0.03-0.3 \mu \mathrm{g} \mathrm{mL}^{-1}$, for malathion, dimethoate, and phorate, respectively. Important analytical parameters such as time, temperature, reagent concentration, acidity etc, have been optimized for complete color reaction. Sandell's sensitivity and molar absorptivity for the system were found to be $0.0002,0.0004,0.0004 \mu \mathrm{g} \mathrm{cm}{ }^{-2}$ and $1.2 \times 10^{6}, 5.21 \times 10^{5}, 6.3 \times 10^{5} \mathrm{~L} \mathrm{~mol}^{-1} \mathrm{~cm}^{-1}$, respectively. The proposed method was satisfactorily applied to micro-level determination of organophosphorus pesticides in vegetable samples.

Keywords: organophosphorus pesticides, potassium iodate, leuco crystal violet, spectrophotometry, vegetables

\section{Introduction}

Organophosphorus pesticides are potentially hazardous substances widely used in agriculture due to their high insecticidal activity. ${ }^{1}$ Organophosphates are organic esters of phosphoric acid, thiophosphoric acid and other phosphoric acids. ${ }^{2}$ These pesticides are toxic for mammals due to the inhibition of the acetyl cholinesterase (AChE), an enzyme necessary for the normal function of the central nervous system. ${ }^{3,4}$ The pesticide residue causes serious health hazard, its ill effect can be reduced to minimum by detecting and then controlling it. ${ }^{5}$ A number

*e-mail: neetuchem30@gmail.com of methods have been developed in the last few years for the detection of organophosphorus pesticides. The most widely used methods are gas chromatography (GC), ${ }^{6-8}$ high-performance liquid chromatography (HPLC), ${ }^{9,10}$ gas chromatography-mass spectrometry (GC-MS), ${ }^{11}$ immune assay and fluorescence, ${ }^{12,13}$ chemiluminescence (CL). ${ }^{14-16}$

Different methods like HPLC, GC and GC-MS have been reported but despite the precision and accuracy of these methods, analyses are restricted to laboratory facilities, are time-consuming and expensive due to its analytical cost, limiting the operation of these instruments to highly qualified laboratory persons. Spectrophotometry is considered the most convenient analytical technique because of its inherent simplicity, low cost, and wide 
availability in most laboratories. Some spectrophotometric methods have also been reported. Most of the methods involve the determination of organophosphorus pesticides by total phosphorous measurements based on the formation of molybdenum blue using various reducing agents. ${ }^{17-19}$ Others are based on the oxidation of pesticide and determination of unconsumed oxidant by bleaching of dye. ${ }^{20}$ Some of the methods suffer from interference, poor sensitivity, instability of color or involve extraction whereas other suffers from blank absorption or longer time required for the color development. To overcome these drawbacks a selective and sensitive method has been proposed for the determination of the studied organophosphorus pesticides.

In the present study a validated, rapid, sensitive, selective kinetic spectrophotometric method for the determination of organophosphorus pesticides is developed. The method is based on the catalytic effect of organophosphorus pesticides on the oxidation of LCV (leuco crystal violet) by potassium iodate in acidic medium. The proposed method is specific for thion compounds containing $\mathrm{P}=\mathrm{S}$ bond like malathoin, dimethoate, phorate. Nowadays these pesticides are increasingly being used in agriculture.

\section{Experimental}

\section{Apparatus and reagents solutions}

A Systronics Visiscan 167 was used for spectral measurements. Measurements of $\mathrm{pH}$ were made with Systronics digital $\mathrm{pH}$ meter 335 . All reagents used were of analytical grade, double distilled deionized water has been used for preparation of solutions. Stock solutions of organophosphorus pesticides, i.e., malathion, phorate, and dimethoate (Northern Minerals Ltd., India) were prepared by dissolving $100 \mathrm{mg}$ of insecticide (technical forms and formulations) in minimum amount of glacial acetic acid (Merck, Mumbai, India) and then diluted to $100 \mathrm{~mL}$ with distilled water. Working standards were prepared by appropriate dilution. Potassium iodate (Merck, Mumbai, India) aqueous solution $4.7 \times 10^{-3} \mathrm{~mol} \mathrm{~L}^{-1}$ was prepared. This was stored in ambar bottle. To prepare $6.7 \times 10^{-4} \mathrm{~mol} \mathrm{~L}^{-1}$ solution of LCV (leuco crystal violet) (Merck, Mumbai, India), $200 \mathrm{~mL}$ of water, $3 \mathrm{~mL}$ of $85 \%$ phosphoric acid and $250 \mathrm{mg}$ of LCV were added to a $1 \mathrm{~L}$ volumetric flask and shaken gently until the LCV dissolved. The content of the flask was then filled to $1 \mathrm{~L}$ with distilled water. The solution was stable for several months. Solutions of $2 \mathrm{~mol} \mathrm{~L}^{-1}$ hydrochloric acid (Merck, Mumbai, India) and $0.2 \mathrm{~mol} \mathrm{~L}^{-1}$ sodium hydroxide (Merck, Mumbai, India) were prepared.

\section{Procedure}

\section{Preparation of the calibration curve}

To a series of $25 \mathrm{~mL}$ volumetric flasks, $1.0 \mathrm{~mL}$ of $6.7 \times 10^{-4} \mathrm{~mol} \mathrm{~L}^{-1} \mathrm{LCV}$ solution, $1.0 \mathrm{~mL}$ of $2.0 \mathrm{~mol} \mathrm{~L}^{-1}$ hydrochloric acid and $1.0 \mathrm{~mL}$ of different concentration of organophosphorus pesticides (malathion, dimethoate and phorate) were added in sequence. Then $1.0 \mathrm{~mL}$ of $4.7 \times 10^{-3} \mathrm{~mol} \mathrm{~L}^{-1}$ potassium iodate solution was added and the $\mathrm{pH}$ was adjusted by adding $0.2 \mathrm{~mol} \mathrm{~L}^{-1} \mathrm{NaOH}$. Following, the solution was diluted to the mark with double distilled water. The zero time was taken as the moment at which the last drop of potassium iodate solution was added and the solution was mixed well. Then the volumetric flasks were placed in a boiling water bath for $15 \mathrm{~min}$ at $35^{\circ} \mathrm{C}$ for completion of the reaction. The content was then cooled under tap water for $3 \mathrm{~min}$ to stop the catalytic reaction. After that, a portion of the solution was transferred into a quartz cell and the absorbance was measured against double distilled water at $592 \mathrm{~nm}$. The blank reaction was performed according to the same procedure without addition of organophosphorus pesticides and the change in absorbance was measured. The standard curve was constructed between the difference between blank and sample absorbance versus time. The absorbance of catalyzed and non-catalyzed reaction was measured simultaneously.

Determination of organophosphorus pesticide in pesticide free samples

To check the recoveries of organophosphorus pesticides, vegetable samples free from organophosphorus pesticides, were taken and treated with a known amount of the organophosphorus pesticide and kept for $c a$. $24 \mathrm{~h}$. The samples were then washed with ethanol. ${ }^{20}$ Different proportions of ethanol were tested for extraction and the best result was obtained with $85 \%$ of ethanol. Then washings were collected and evaporated and residue is dissolved in $0.1 \%$ acetic acid. Aliquots of these washings were used for the determination of organophosphorus pesticide by the proposed method. The proposed method was successfully applied for the determination of organophosphorus pesticide in vegetable samples. The recovery range is summarized in Table 3.

\section{Results and Discussion}

LCV (leuco crystal violet) is a compound which can be oxidized with potassium iodate at very slow reaction rate. It has been reported that organophosphates have an induction effect on iodine azide reaction. ${ }^{22}$ Similarly, in the proposed method organophosphorus pesticides act as a catalyst in the 


\section{Reaction scheme 1}

$$
\begin{aligned}
& \mathrm{IO}_{3}{ }^{-}+\mathrm{H}^{+}+\mathrm{LCV}(\text { reduced }) \rightarrow \mathrm{I}^{-}+\mathrm{CV}(\text { oxidized }) \text {------------(1) [Slow reaction] } \\
& \mathrm{IO}_{3}{ }^{-}+\mathrm{H}^{+}+\mathrm{OPP} \rightarrow \mathrm{I}^{-}+\mathrm{OPP}(\text { oxidized }) \text {-------------(2) }[\text { Fast reaction] } \\
& \mathrm{IO}_{3}{ }^{-}+\mathrm{H}^{+}+\mathrm{I}^{-} \rightarrow \mathrm{I}_{2}+\mathrm{H}_{2} \mathrm{O} \text {-----------(3) }[\text { Fast reaction] } \\
& \mathrm{I}_{2}+\mathrm{H}^{+}+\mathrm{LCV}(\text { reduced }) \rightarrow \mathrm{I}^{-}+\mathrm{CV}(\text { oxidized) }------------(4)
\end{aligned}
$$

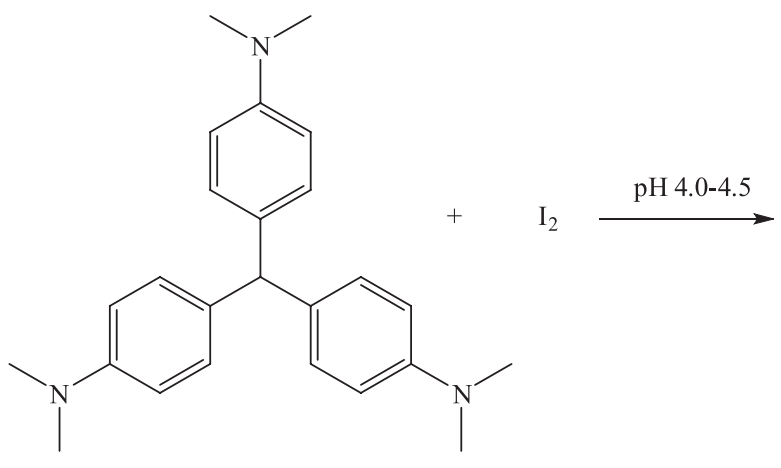

Leuco crystal violet<smiles>CN(C)c1ccc(C(=C2C=CC(=[N+](C)C)C=C2)c2ccc(N(C)C)cc2)cc1</smiles>

Crystal violet

Scheme 1.

reaction between $\mathrm{LCV}$ and potassium iodate in the presence of hydrochloric acid medium. An organophosphorus pesticide increases the rate of this reaction at ultra trace level. Therefore, by measuring the increase in absorbance of $\mathrm{CV}$ (crystal violet), which is the oxidized product of LCV, for a fixed time of $15 \mathrm{~min}$ of the reaction, the organophosphate content in the sample can be measured. It was observed that such type of catalytic activity was mainly exhibited by thiophosphoryl compounds and depends on the nature of the $\mathrm{P}=\mathrm{S}$ bond, so the organophosphorus pesticide like monocrotophose which do not have $\mathrm{P}=\mathrm{S}$ bond, does not show the catalytic activity. The probable mechanism of the catalytic reaction is given in reaction Scheme 1.

\section{Effect of acid concentration}

The effect of various acids of same concentration such as sulphuric acid, acetic acid, nitric acid has been studied. The results show that hydrochloric acid gives greater sensitivity. The effect of hydrochloric acid concentration on obtaining maximum sensitivity was investigated with $4.7 \times 10^{-3} \mathrm{~mol} \mathrm{~L}^{-1}$ potassium iodate, and $6.7 \times 10^{-4} \mathrm{~mol} \mathrm{~L}^{-1}$ $\mathrm{LCV}$ for catalyzed and non-catalyzed reaction at $35{ }^{\circ} \mathrm{C}$ (Figure 1 ).

\section{Effect of potassium iodate concentration}

The effect of potassium iodate concentration in the reaction rate was studied with $2 \mathrm{~mol} \mathrm{~L}^{-1}$ hydrochloric

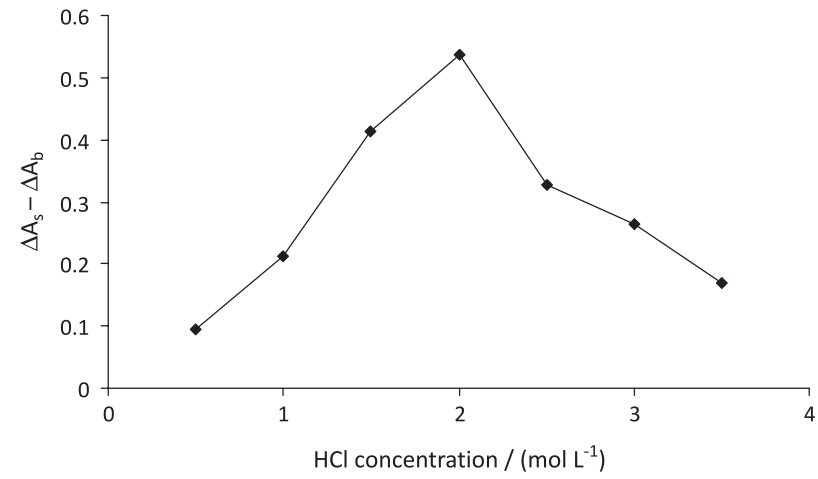

Figure 1. Effect of $\mathrm{HCl}$ concentration on the sensitivity. Conditions: OPP: $0.12 \mu \mathrm{g} \mathrm{mL}{ }^{-1}$; LCV: $6.7 \times 10^{-4} \mathrm{~mol} \mathrm{~L}^{-1}$; potassium iodate: $4.7 \times 10^{-3} \mathrm{~mol} \mathrm{~L}^{-1}$; temperature: $35^{\circ} \mathrm{C}$.

acid and $6.7 \times 10^{-4} \mathrm{~mol} \mathrm{~L}^{-1} \mathrm{LCV}$ at $35^{\circ} \mathrm{C}$. The results show that by increasing the potassium iodate concentration up to $4.7 \times 10^{-3} \mathrm{~mol} \mathrm{~L}^{-1}$ the sensitivity increases, whereas a greater amount of reagent decreases sensitivity. Thus $4.7 \times 10^{-3} \mathrm{~mol} \mathrm{~L}^{-1}$ potassium iodate was selected throughout the study (Figure 2).

\section{Effect of leuco crystal violet concentration}

The influence of $\mathrm{LCV}$ concentration on the reaction rate was studied in the range of $1 \times 10^{-4}$ to $10 \times 10^{-4} \mathrm{~mol} \mathrm{~L}^{-1}$ with 2 mol L ${ }^{-1}$ hydrochloric acid and $4.7 \times 10^{-3} \mathrm{~mol} \mathrm{~L}^{-1}$ potassium iodate at $35{ }^{\circ} \mathrm{C}$. The results show that by increasing the LCV concentration up to $6.7 \times 10^{-4} \mathrm{~mol} \mathrm{~L}^{-1}$, the sensitivity increases, whereas a greater amount of reagent decreases 
sensitivity, thus $6.7 \times 10^{-4} \mathrm{~mol} \mathrm{~L}^{-1} \mathrm{LCV}$ was selected for the study (Figure 3).

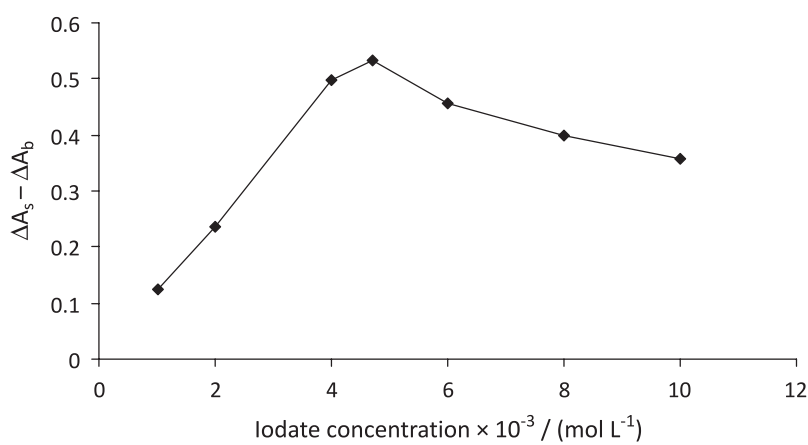

Figure 2. Effect of iodate concentration on the sensitivity. Conditions: OPP: $0.12 \mu \mathrm{g} \mathrm{mL}^{-1}$; hydrochloric acid: $2 \mathrm{~mol} \mathrm{~L}^{-1}$; LCV: $6.7 \times 10^{-4} \mathrm{~mol} \mathrm{~L}^{-1}$; temperature: $35^{\circ} \mathrm{C}$.

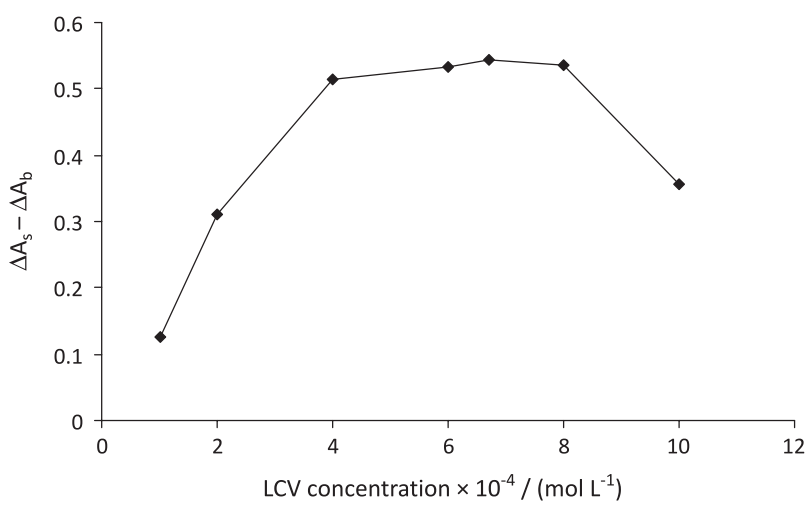

Figure 3. Effect of LCV concentration on the sensitivity. Conditions: OPP: $0.12 \mu \mathrm{g} \mathrm{mL}^{-1}$; hydrochloric acid: $2 \mathrm{~mol} \mathrm{~L}^{-1}$; potassium iodate: $4.7 \times 10^{-3} \mathrm{~mol} \mathrm{~L}^{-1}$; temperature: $35^{\circ} \mathrm{C}$.

\section{Effect of temperature and time}

The effect of temperature on the catalytic reaction was studied in the range of $10^{\circ} \mathrm{C}$ to $70^{\circ} \mathrm{C}$ with the optimum of the reagent concentrations. The results showed that as the temperature increases up to $35^{\circ} \mathrm{C}$ the sensitivity increases, whereas higher temperature values decreases the sensitivity $\left(\Delta \mathrm{A}_{\mathrm{s}}-\Delta \mathbf{A}_{\mathrm{b}}\right)$. Therefore, $35^{\circ} \mathrm{C}$ was selected for further study and 15 min time was suitable for the study of catalytic reaction (Figure 4).

\section{Spectral characteristics and method validation}

The absorption spectra of final colored product showed a maximum absorbance at $592 \mathrm{~nm}$ (Figure 5). The reagent blank had negligible absorbance at this wavelength. Beer's law was obeyed over the concentration range of 0.02-0.2, 0.032-0.32, 0.03-0.3 $\mu \mathrm{g} \mathrm{mL} \mathrm{mL}^{-1}$ for malathion, dimethoate and phorate, respectively (Figure 6). The curve was linear with different slopes for malathion, dimethoate, phorate

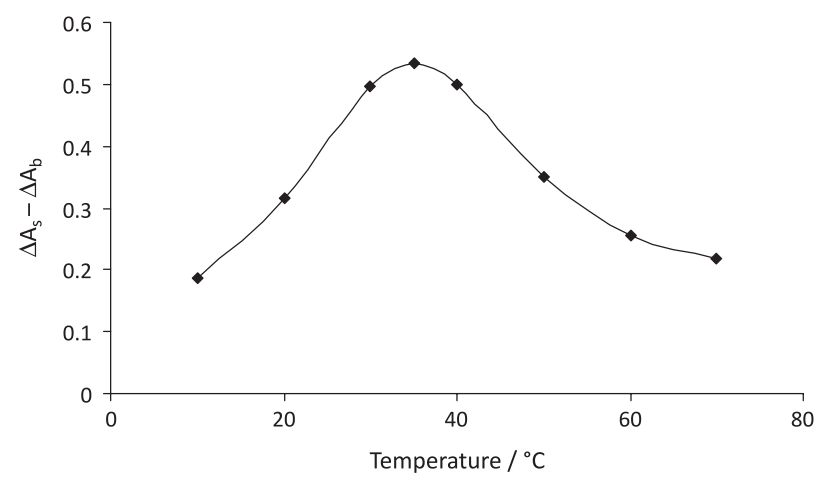

Figure 4. Effect of temperature on the sensitivity. Conditions: OPP: $0.12 \mu \mathrm{g} \mathrm{mL}-1$ LCV: $6.7 \times 10^{-4} \mathrm{~mol} \mathrm{~L}^{-1}$; hydrochloric acid: $2 \mathrm{~mol} \mathrm{~L}^{-1}$; potassium iodate: $4.7 \times 10^{-3} \mathrm{~mol} \mathrm{~L}^{-1}$.

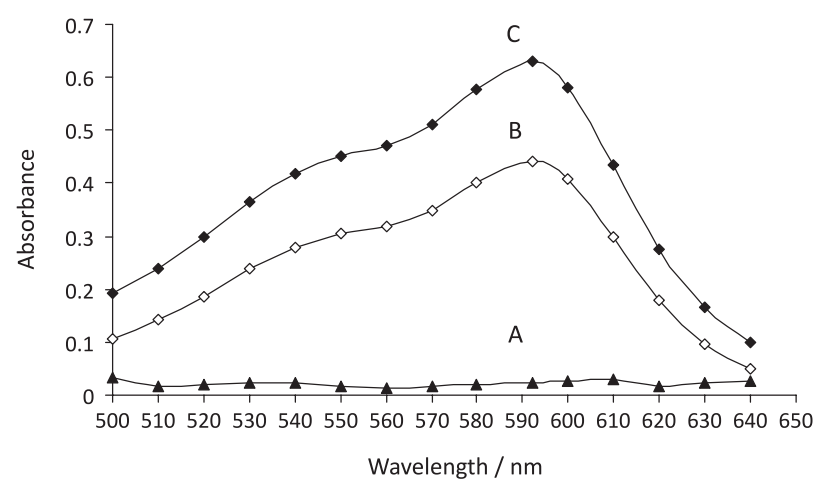

Figure 5. Absorption spectra of colored product; A: blank, B: $0.1 \mu \mathrm{g} \mathrm{mL} \mathrm{L}^{-1}$, C: $0.14 \mu \mathrm{g} \mathrm{mL}{ }^{-1} \mathrm{OPP}$.

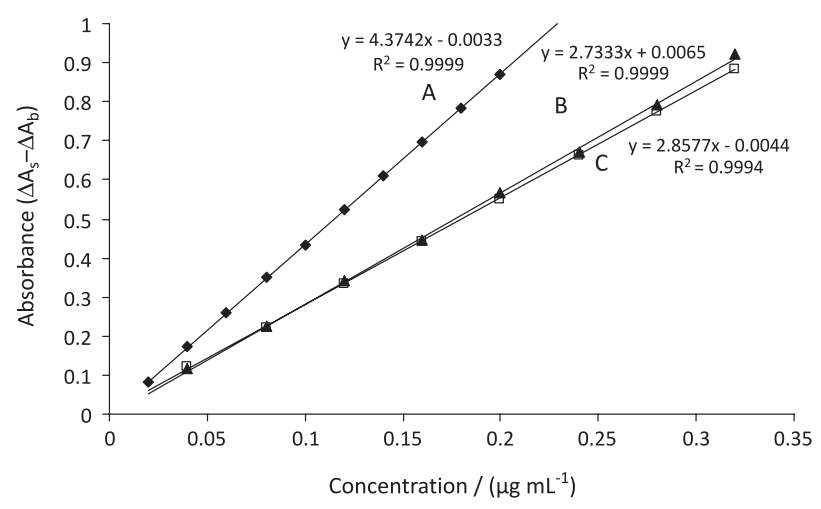

Figure 6. Calibration data for the determination of organophosphorus pesticide; A: malathion; B: dimethoate; C: phorate.

and has a good correlation. The molar absorptivities and Sandell's sensitivity of malathion, dimethoate, phorate are given in Table 1. The slope, intercept, and the correlation coefficient were calculated by least square regression analysis (Table 1).The limits of detection and quantitation ( $\mathrm{LOD}=3.3 \sigma / \mathrm{S}$ and $\mathrm{LOQ}=10 \sigma / \mathrm{S}$, where $\sigma$ is the slope of the calibration curve), SD of slope and intercept calculated are given in Table 1. The precision of the method was calculated in terms of intermediate precision (intra-day and inter-day). Three different concentrations of OPP 
Table 1. Analytical and method validation parameters

\begin{tabular}{lccc}
\hline Parameters & Malathion & Dimethoate & Phorate \\
\hline$\lambda_{\text {max }} / \mathrm{nm}$ & 592 & 592 & 592 \\
Range of Beer's law / $\left(\mu \mathrm{g} \mathrm{mL}^{-1}\right)$ & $0.02-0.2$ & $0.032-0.32$ & $0.03-0.3$ \\
Stability of color / $\mathrm{h}$ & 48 & 48 & 48 \\
Molar absorptivity / $\left(\mathrm{L} \mathrm{mol}^{-1} \mathrm{~cm}^{-1}\right)$ & $1.2 \times 10^{6}$ & $5.2 \times 10^{5}$ & $6.3 \times 10^{5}$ \\
Sandell's sensitivity / $\left(\mu \mathrm{g} \mathrm{cm}{ }^{-2}\right)$ & 0.0002 & 0.0004 & 0.0004 \\
Relative standard deviation / \% & & & \\
Intra-day & $0.466-3.278$ & $0.46-2.6$ & $0.53-2.7$ \\
Inter-day & $1.11-3.37$ & $0.65-1.48$ & $0.59-4.5$ \\
Limit of Detection & 0.004 & 0.008 & 0.007 \\
Limit of Quantification & 0.01 & 0.02 & 0.02 \\
SD of slope & 0.084 & 0.064 & 0.059 \\
SD of intercept & 0.006 & 0.016 & 0.017 \\
Regression equation $(\mathrm{y}=\mathrm{bx}+\mathrm{a})^{*}$ & & & \\
Correlation coefficient & 0.999 & 0.999 & 0.999 \\
Slope (b) & 4.37 & 2.73 & 2.86 \\
Intercept (a) & -0.0033 & 0.0065 & -0.0044 \\
\hline
\end{tabular}

*Concentration in $\mu \mathrm{g} \mathrm{mL} \mathrm{m}^{-1}$.

(organophosphorus pesticides), within the working limits, were analyzed in seven replicates during the same day (intra-day precision) and seven consecutive days (inter-day precision). The RSD (\%) values range of intra-day and inter-day studies showed that the precision was good for the method (Table 1).

\section{Interference studies}

The effect of foreign ions and pesticides expected to exist in field samples of organophosphorus pesticide were studied by adding known amount of different foreign ions to the test solution containing $0.1 \mu \mathrm{g} \mathrm{mL} \mathrm{L}^{-1}$ organophosphorus pesticide. The method was found to be free from most of the interferents. The tolerance limits shown in Table 2 are the concentration of interfering species that may cause variation $\geq( \pm) 2 \%$ in the absorbance value.

\section{Application}

Determination of organophosphorus pesticides in real vegetable samples

Vegetable samples were collected from agricultural field where organophosphorus pesticide (malathion) was sprayed ( 1 to 5 pints per acre). The samples were weighed, macerated with ethanol and then filtered through a thin cotton cloth. The filtrate was centrifuged at $1850 \mathrm{~g}$ for $10 \mathrm{~min}$. An aliquot of supernatant was taken and evaporated then residue is dissolved in $0.1 \%$ acetic acid and analyzed as described above. The filtrate which was greenish yellow due to the presence of organic matter from plant was passed through a silica gel column $(10 \times 1 \mathrm{~cm})$ to remove chlorophyll and other interfering materials. The column was washed with $10 \mathrm{~mL}$ of $0.1 \%$ acetic acid. Washings were collected and analyzed as recommended above by the proposed as well as the conventional ascorbic acid method ${ }^{21}$ and the results are shown in Table 4.

Table 2. Effect of foreign species (concentration of organophosphorus pesticides $0.1 \mu \mathrm{g} \mathrm{mL} L^{-1}$ )

\begin{tabular}{lc}
\hline Foreign species & $\begin{array}{c}\text { Tolerance limit / } \\
\left(\mu \mathrm{g} \mathrm{mL}^{-1}\right)^{\mathrm{a}}\end{array}$ \\
\hline $\mathrm{SO}_{4}^{2-}, \mathrm{CO}_{3}^{2-}, \mathrm{CH}_{3} \mathrm{COO}^{-}$, benzene, acetone & 1000 \\
$\mathrm{Se}^{4+}, \mathrm{Fe}^{2+}$ & 500 \\
aniline & 250 \\
atrazine, pyrethroid pesticide & 250 \\
$\mathrm{Cr}^{3+}, \mathrm{Cd}^{2+}, \mathrm{Mg}^{2+}, \mathrm{Na}^{+}, \mathrm{K}^{+}, \mathrm{Mn}^{2+}, \mathrm{Al}^{3+}, \mathrm{NH}_{4}^{+}, \mathrm{NO}_{3}^{-}, \mathrm{F}^{-}$ & 200 \\
${ }^{b} \mathrm{Zn}^{2+}$ & 100 \\
dithiocarbamate pesticides & 40 \\
carbamate pesticides & 15 \\
{$\left[\mathrm{Br}{ }^{-}, \mathrm{I}^{-}\right]^{\mathrm{c}}$} & 10 \\
Phenol & 8 \\
\hline
\end{tabular}

aCausing $( \pm) 2 \%$ variation in absorbance value; ${ }^{b}$ masking with $0.1 \%$ EDTA solution; 'removed by addition of nitric acid as well as boiling the solution.

Table 3. Determination of organophosphorus pesticide in pesticide free samples

\begin{tabular}{|c|c|c|c|c|c|c|c|c|c|}
\hline \multirow[b]{2}{*}{ Samples ${ }^{\mathrm{a}}$} & \multicolumn{3}{|c|}{ Malathion } & \multicolumn{3}{|c|}{ Dimethoate } & \multicolumn{3}{|c|}{ Phorate } \\
\hline & $\begin{array}{c}\text { Added / } \\
\mu \mathrm{g}\end{array}$ & $\begin{array}{c}\text { Found }^{\mathrm{b}} / \\
\mu \mathrm{g}\end{array}$ & $\begin{array}{c}\text { Rec. / } \\
\%\end{array}$ & $\begin{array}{c}\text { Added / } \\
\mu \mathrm{g}\end{array}$ & $\begin{array}{c}\text { Found }{ }^{\mathrm{b}} / \\
\mu \mathrm{g}\end{array}$ & $\begin{array}{c}\text { Rec. / } \\
\%\end{array}$ & $\begin{array}{c}\text { Added / } \\
\mu \mathrm{g}\end{array}$ & $\begin{array}{c}\text { Found }^{\mathrm{b}} / \\
\mu \mathrm{g}\end{array}$ & $\begin{array}{c}\text { Rec. I } \\
\%\end{array}$ \\
\hline \multirow[t]{3}{*}{ Cauliflower } & 20 & 18.5 & 92.5 & 20 & 18.92 & 94.6 & 20 & 18.75 & 93.75 \\
\hline & 40 & 38.2 & 95.5 & 40 & 39.12 & 97.8 & 40 & 38.33 & 95.82 \\
\hline & 60 & 59.1 & 98.5 & 60 & 59.13 & 98.55 & 60 & 58.75 & 97.91 \\
\hline \multirow[t]{3}{*}{ Cabbage } & 20 & 19.4 & 97 & 20 & 19.16 & 95.8 & 20 & 19.06 & 95.3 \\
\hline & 40 & 39.2 & 98 & 40 & 38.75 & 96.87 & 40 & 39.16 & 97.9 \\
\hline & 60 & 58.5 & 97.5 & 60 & 58.93 & 98.21 & 60 & 58.55 & 97.58 \\
\hline \multirow[t]{3}{*}{ Spinach } & 20 & 19.2 & 96 & 20 & 19.77 & 98.85 & 20 & 18.88 & 94.4 \\
\hline & 40 & 38.8 & 97 & 40 & 39.43 & 98.57 & 40 & 38.46 & 96.15 \\
\hline & 60 & 58.1 & 96.83 & 60 & 58.84 & 98.06 & 60 & 59.31 & 98.85 \\
\hline
\end{tabular}

${ }^{\mathrm{a}}$ Amount of sample: $25 \mathrm{~g} ;{ }^{\mathrm{b}}$ mean of three replicate analysis. 
Table 4. Application of the method on real samples

\begin{tabular}{lcc}
\hline Vegetable sample $^{\mathrm{a}}$ & \multicolumn{2}{c}{ Organophosphorus pesticide found $/ \mu \mathrm{g}^{\mathrm{b}}$} \\
\cline { 2 - 3 } & Present method & Conventional method ${ }^{21}$ \\
\hline Cauliflower & 2.25 & 2.23 \\
& 4.52 & 4.50 \\
& 1.79 & 1.45 \\
Cabbage & 6.59 & 6.35 \\
& 4.89 & 4.62 \\
& 2.64 & 2.36 \\
Spinach & 1.88 & 1.55 \\
& 2.52 & 2.50 \\
& 3.65 & 3.49 \\
\hline
\end{tabular}

${ }^{a}$ Amount of vegetable samples (from fields where organophosphorus pesticides were sprayed): $25 \mathrm{~g}$; ${ }^{\mathrm{b}}$ mean of three replicate analysis.

Ascorbic acid method involves the reaction of orthophosphate with molybdate in acid solution, which forms a yellow-colored phosphomolybdate. The phosphomolybdate complex is then reduced by ascorbic acid, causing a characteristic molybdenum blue species which is measured at $700 \mathrm{~nm}$.

\section{Conclusions}

The proposed method is more sensitive, simple and selective as compared with other spectrophotometric methods for determination of organophosphorus pesticides. The reported spectrophotometric methods are indirect, lengthy, time consuming, suffer from interference, poor sensitivity, instability of color, blank absorption or involve extraction. The rapid color development, stability and easy availability of the reagent and freedom from a large group of interfering species are some advantages of the method. As the presented method is based on catalytic effect on rate of reaction it can be further applied for simultaneous determination of these pesticides by applying initial rate and partial least square regression analysis method.

\section{Acknowledgments}

The authors are thankful to Government V. Y .T. PG Autonomous College, Durg for laboratory facilities and to Northern Minerals Ltd. India for free pesticide samples.

\section{References}

1. Li, A. F.; Liu, X. Y.; Kong, J.; Hu, H. Y.; Sun, L. H.; Qian, Z.; J. AOAC Int. 2009, 92, 914.

2. Al-Samariee, A. I.; Khloud, A. M.; Al-Bassomy, M. A.; Pesticide Sci. 1988, 22, 189.

3. Taira, K.; Aoyama, Y.; Kawamata, M.; Environ. Toxicol. Pharmacol. 2006, 22, 40.

4. Inoue, S.; Saito, T.; Mase, H.; Suzuki, Y.; Takazawa, K.; Yamamoto, I.; Inokuchi, S.; J. Pharm. Biomed. Anal. 2007, 44, 258.

5. Li, B. X.; He, Y. Z.; Xu, C. L.; Talanta 2007, 72, 223.

6. Ahmadi, F.; Assadi, Y.; Rezaee, M.; J. Chromatogr. 2006, 1101, 307.

7. Jin, Y.; Yao, J. B.; Fu, H. B.; Pan, W.; Geng, Q. H.; Ma, W.; Chin. J. Health Lab. Technol. 2007, 17, 1153.

8. Knet, A. C. L.; Seng, L.; Pertanika J. Sci. Technol. 2003, 11, 93.

9. Cho, Y.; Matsuoka, N.; Kamiya, A.; Chem. Pharm. Bull. 1997, 45,737

10. Martinez, R. C.; Gonzalo, E. R.; García, F. G.; Méndez, J. H.; J. Chromatogr. A 1993, 644, 49.

11. Lu, J. Z.; Lau, C.; Lee, M. K.; Ka, M.; Anal. Lett. 2002, 455, 193.

12. Suvardhan, K.; Kumar, K.; Chiranjeevi, P.; Environ. Monit. Assess. 2005, 108, 217.

13. Viveros, L.; Paliwal, S.; McCrae, D.; Wild, J.; Simonian, A.; Sensor Actuat. B-Chem. 2006, 115, 150.

14. Li, A.; Liu, X.; Kong, J.; Huang, R.; Wu, C.; Anal. Lett. 2008, $41,1375$.

15. Lau, C.; Lu,J. Z.; Kai, M.; Anal. Lett. 2004, 503, 235.

16. Li, B.; Zhang, Z.; Jin, Y.; Anal. Chem. 2001, 73, 1203.

17. Sunita, S.; Gupta, V. K.; J. Ind. Chem. Soc. 1987, 65, 114.

18. Getenga, Z. M.; Jandiiko, J. I. O; Wandigo, S. O.; Beck, E.; Bull. Environ. Contam. Toxicol. 2000, 64, 359.

19. Raju, J.; Gupta, V. K.; Microchem. J. 1989, 39, 166.

20. Mathew, S. B.; Pillai, A. K.; Gupta, V. K.; Electron. J. Environ. Agric. Food Chem. 2006, 5, 1604.

21. Lowry, O. H.; Lopez, J. A.; J. Biol. Chem. 1946, 162, 421.

22. Kotynski, A.; Kudzin, Z. H.; Ciesielski, W.; Folia Chimica 2004, 13, 135 .

Submitted: August 4, 2011

Published online: December 13, 2011 